\title{
US 145 Citrus Breeding Line
}

\section{H.C. Barrett ${ }^{1}$ \\ U.S. Horticultural Research Laboratory, U.S. Department of Agriculture, Agricultural Research Service, 2120 Camden Road, Orlando, FL 32803}

Additional index words. Citrus grandis, fruit breeding, combining ability

The U.S. Dept. of Agriculture (USDA), Agricultural Research Service, started a citrus breeding program in 1973 . The objective was to develop improved scion cultivars resistant to freeze injury and citrus tristeza virus (CTV) (Barrett, 1981). One breeding line, US119 (an intergeneric hybrid combining cold and CTV resistance with edible fruit), was released to citrus breeders (Barrett, 1990). Poncirus trifoliata (L.) Rafinesque, an inedible relative of citrus, has been the most genetically useful source of traits for cold and CTV resistance in that research program. Poncirus trifoliata carries traits for repulsive fruit qualities that also are transmitted in varying degree to hybrid progeny when crossed with citrus cultivars. It has been difficult to find citrus cultivars with sufficient combining ability to produce any hybrid offspring with edible fruit in crosses where the resulting progenies carried even one-quarter Poncirus inheritance. The citrus breeding line US 145, a seedling pummelo (Citrus grandis Osbeck), has demonstrated superior combining ability for edibility in intergeneric crosses involving $P$. trifoliata inheritance and other desirable traits useful to citrus breeders.

\section{Origin}

US 145 is a selection from Thong Dee pumelo seedlings grown from seed collected in the USDA germplasm collection by Ken Scudder and planted at Orlando, Fla., in 1947. Beginning in 1976, the seedlings were evaluated for various attributes, and I selected US 145 in 1981 for further breeding research.

\section{Description}

The tree of US 145 is moderately vigorous and upright spreading, becoming more spreading with age. The foliage is medium-dark green, unifoliate, and typical of pummelo in size and shape. Trees bear fruit singly and in clusters. The globose fruit are $\approx 150 \mathrm{~mm}$ in diameter and weigh $\approx 1300 \mathrm{~g}$ (Fig. 1). The rind is smooth, yellow, nonpubescent, and $\approx 12 \mathrm{~mm}$

Received for publication 23 Aug. 1993. Accepted for publication 6 Nov. 1993. Mention of a trademark, warranty, proprietary product, or vendor does not constitute a guarantee by the U.S. Dept. of Agriculture and does not imply its approval to the exclusion of other products or vendors that may also be suitable. The cost of publishing this paper was defrayed in part by the payment of page charges. Under postal regulations, this paper therefore must be hereby marked advertisement solely to indicate this fact.

'Research Geneticist. thick. The flesh is moderately firm, light yellow, juicy, and, in my opinion, has good flavor. US 145 ranks as one of the best two or three pummelo cultivars or selections for fruit quality evaluated in the USDA citrus germplasm collection. In Florida, fruit matures in midseason. Juice samples range from 12.1910 to $15.2 \%$ total soluble solids concentration and titratable acidity from $1.05 \%$ to 1.1390 . There are 12 to 16 segments per fruit with a variable number of monoembryonic seeds (4070). Many full size, nearly seedless fruit are also produced.

US 145 is one of only two citrus clones in the germplasm collection that has demonstrated superior combining ability to produce selections from $\mathrm{BC}_{1}$ progeny with one-quarter
$P$. trifoliata inheritance that combine edibility and sufficient cold hardiness to survive and produce fruit following freezes as severe as the disastrous 1989 Florida freeze. US 145 is similar to other pummelo cultivars in its susceptibility to freeze injury of the foliage and current-season's growth; however, this clone can produce flowers and set mature normalized fruit from new growth derived from the tissue of 4- and 5-year-old branches after freezes have destroyed the current-season's growth.

\section{Availability}

A limited supply of US 145 budwood, indexed and found free of exocortis virus, is available from Farm Superintendent, A.H. Whitmore Foundation Farm, U.S. Dept. of Agriculture, Agricultural Research Service, 23402 USDA Road, Groveland, FL 34746.

\section{Literature Cited}

Barrett, H.C. 1981. Breeding cold-hardy citrus scion cultivars. Proc. Intl. Soc. Citricult. 1:61-66.

Barrett, H.C. 1990. US 119, An intergeneric hybrid citrus scion breeding line. HortScience 25:16701671
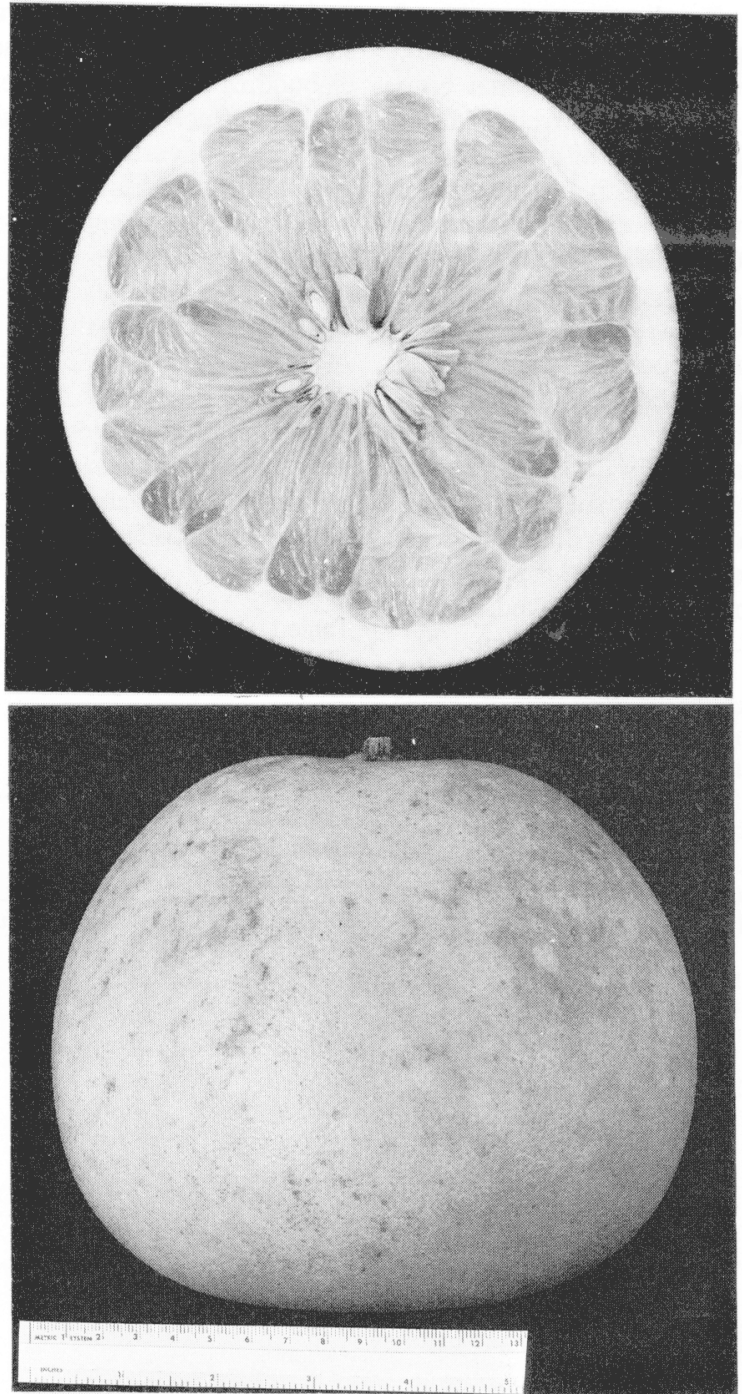

Fig. 1. Fruit of US 145. 